\author{
BIG DATA AND ANTITRUST LAW ${ }^{1}$ \\ Big Data y Derecho de la Competencia \\ CARMEN HERRERO SUÁREZ \\ Associate Professor of Business Law \\ Commercial Law Department \\ University of Valladolid \\ Pz/Universidad s/n 47002 Valladolid (Spain) \\ Email: carmen.herrero.suarez@uva.es \\ ORCID: 0000-0002-9870-9936
}

\begin{abstract}
"The statement "If you don't like Google, you can remove yourself from their listings and go elsewhere," is about as realistic as recommending to an opponent of nuclear power that he just stop using electricity $(\ldots)^{2}$,
\end{abstract}

\begin{abstract}
The technological revolution we have witnessed in recent years had led to the appearance of a new term within the framework of the digital economy: Big Data. The rise and consolidation of enterprises with major volumes of production based on business models that involve the gathering and processing of personal data has caused misgivings amongst the competition authorities, and has led to a conflict between defenders of the pro-competitive nature of Big Data and those who take a more sceptical view, who have warned of the possibility that these data policies may be used by companies as a tool for creating, consolidating, and extending their positions of power in the market.
\end{abstract}

Keywords: Big Data, market power, algorythms, two-sided markets, privacy

Resumen: La revolución tecnológica de los últimos años ha propiciado la aparición de un nuevo término en el marco de la economía digital: la economía de los grandes datos o Big Data. El surgimiento y consolidación de empresas con importantes volúmenes de producción basadas en modelos de negocios que implican la recolección y procesamiento de datos personales ha despertado los recelos de las autoridades de la competencia y ha propiciado la apertura de un debate que enfrenta a defensores del carácter procompetitivo del Big Data con otras posiciones más escépticas que alertan sobre la posibilidad de que las políticas de datos puedan ser utilizadas por las empresas como un instrumento de creación, consolidación o extensión de posiciones de poder de mercado.

\footnotetext{
${ }^{1}$ This study forms a part of the Research Project untitled "Proyecto de Investigación: "Distribución y Competencia: retos y problemas en el marco de una economía global y digitalizada" (VA015G18), de la Consejería de Educación de Castilla y León.

${ }^{2}$ MATHIAS, DöPFNER: “An Open Letter to Eric Schmidt: Why Do We Fear Google?" Frankfurt Allgemeine, 17 April 2014.
} 
Palabras clave: Big Data, poder de mercado, algoritmos, mercados de doble faz, privacidad

\section{THE NEW DATA ECONOMY}

1.1.The importance and value of data: what has changed?

1.2.The concept and characteristics of Big Data

1.3 The positive and negative effects of Big Data

\section{THE PHENOMENON OF BIG DATA FROM THE PERSPECTIVE OF} ANTITRUST LAW

2.1. A change of course by the competition authorities

2.2. Big data and market power

2.3. The application of anti-trust regulations: possible risks for competition

2.3.1. The suitability of traditional tools and privacy as an interest protected by Competition Law

2.3.2. Collusive practices

2.3.3. Control of concentrations

2.3.4. Abuse of a dominant position

\section{AN UNCERTAIN FUTURE}

\section{THE NEW DATA ECONOMY}

\subsection{The importance and value of data: what has changed?}

The digital revolution that has taken place over the last few decades has undoubtedly had a striking effect on economic activity, moulding and redirecting the way that companies do business. The exponential growth of electronic procurement in the sale of products and provision of services (such as transportation, banking, or insurance); the appearance of the so-called collaborative economy platforms; the offer of new business services, such as web browsers or price comparison sites; the rise of different types of social networks that explore new relational possibilities, or more recently the internet of things $^{3}$, are just a few of the many manifestations of the digital economy. All of these virtual activities share one basic characteristic: their ability to generate or produce information. This information can be used to obtain profits, whose gradual growth has given rise to the appearance of a new expression within the digital economy: the data economy, or more precisely, in its most widespread form, the Big Data economy.

\footnotetext{
${ }^{3}$ The so-called "Internet of things" refers to digital communication between objects. It involves the design of an interconnected network structure that allows different devices to communicate with each other with the ability to compile, transmit, and analyse data (including smart electrical appliances, watches, alarms, or webcams with movement sensors).
} 
In this sense, in recent years the markets have seen the appearance of companies with considerable production volumes based on business models that precisely involve the gathering and commercial use of data or information that is generally of a personal nature. Some of them have very high numbers of users in the service sector in which they operate (such as the Google search engine, or Facebook). The business model of these companies is representative of this new data economy, and forms a part of what are known as two-sided or multisided markets. These markets are characterised by the existence of a platform that puts two different groups in contact with each other, selling or offering two or more products or services to the two groups of consumers, with indirectly related demands. One of the main characteristics of these markets is the interdependence between both sides of the market, which may lead the platform to opt for price-fixing strategies that make it possible to subsidise the side of the market that is most price-sensitive by the side that is more sensitive to the size of the other side of the market. In order to maximise profits, the platform may choose to offer the service freely in order to obtain higher income from the other part of the market based on the increased amount of information obtained as a result of offering the service for free. For example, Google offers free services (or at least with no monetary cost) to its users, such as an internet browser or translation service, in exchange for obtaining a large amount and variety of data for which advertisers will pay in order to promote their products in a more personal and effective way ${ }^{4}$. This 'freemium' service strategy also applies to the business policy of Facebook, which offers free access to a social network.

This said, the data economy does not only affect search engines, social networks, or online publicity. Information and the development of ways of obtaining and processing data is equally relevant in other sectors such as energy, telecommunications, insurance, banking, or transportation. In fact, the gradual development of the Internet of Things will be decisive in data not only being important in the services market, but also extending to the products market.

But what do the terms data or Big Data really mean? Before examining the different definitions and structural features of this data, we need to clarify two issues. Firstly, at least in terms of consumer protection or competition with regard to the use of information by different undertakings, this refers to personal data, referring to a natural person who has been identified, or who is identifiable . $^{5}$

\footnotetext{
${ }^{4}$ On the operation of two-sided markets, see FuEnSAntA, AlCARAZ: "Mercados de doble cara (I): Características y estrategia", 2017, available at http://blognewdeal.com. This is one of the structural characteristics of the data economy that can have the most implications in terms of competition, and which as we will see later on, calls for a solid understanding of these markets by the competition authorities in order to evaluate the real scope of business behaviour in the provision of free services in all of the different sectors that are involved.

${ }^{5}$ See Article 2 of Directive 95/46/EC of the European Parliament and of the Council of 24 October 1995 on the protection of individuals with regard to the processing of personal data and on the free movement of such data.
} 
Secondly, in order to be able to understand this phenomenon and its implications, it is necessary to consider that this is quite a novel situation. The search for data by companies or attempts to harvest information on clients or consumers in general, in order to create or improve products or services, or in order to design tailor-made publicity, is something that has always existed, in the form of coupons, loyalty cards, questionnaires, and the like ${ }^{6}$. In parallel to what has happened in the collaborative economy, there has been a change of scale. What has changed is the amount of information being produced, and the possibility of obtaining some type of economic benefit from it. What are the factors that have led to this new situation? The current ability to gather vast amounts of information and process it quickly is the result of the convergence of a series of technological factors. The first is the dematerialisation of information by digitalising it. As indicated by the Competition Authority of Catalonia (Autoridad Catalana de la Competencia), a phenomenon has occurred whereby material elements (made of atoms) have been transformed into information (made of 'bits') ${ }^{7}$. We are living in an era of 'datafication,' in which all of the different facets of our life (our professional or free-time activities, for example) can be converted into data. In addition to this dematerialisation of information are the current possibilities of digital interaction thanks to the development of the internet and permanent connectivity thanks to the growth of mobile devices such as smartphones and tablets. The production and capture of data is easier in the era of the 'relational Internet' or 'Internet 2.0,' which allows for digital contact and communication between subjects, and increasingly between objects.

Every day, millions and millions of bytes of information are produced on all types of situations and activities. This information may be the result of e-commerce transactions, in which clients voluntarily provide their personal data, such as the possibility of monitoring their purchasing history. But it is not only this: a query typed into a search engine such as Google is information. A tweet is information. A 'like' on Facebook or Instagram is information; so is a comment on a hotel reservation website, or an opinion about a restaurant. Information that is produced, spread or stored using methods as varied as mobile telephones, social networks, or the memory of a security camera, a heart rate monitor, or a smart refrigerator.

Finally, this massive production of digital information has been accompanied by the development of new techniques that make it possible to process this mass of data, reducing the amount of time required ${ }^{8}$. This has led to information, whether in the form

\footnotetext{
${ }^{6}$ The gathering, processing, and analysis of large amounts of data is also carried out by the public authorities. JAVIER, PUYOL MONTERO: Aproximación jurídica y económica al Big Data, Tirant lo Blanch, Valencia, 2015, p. 23 , includes the example of one of the first large-scale data gathering projects, the production of the US census in 1790.

${ }^{7}$ Autoritat Catalana de la Competéncia: La Economía de los Datos. Retos para la competencia, 2016, p.6.

${ }^{8}$ See Bundeskartellamt/Autorité De la Concurrence: Competition Law and Data, 2016, p.8; JaVier Puyol Montero, cit., pp. 22 ff. For a detailed examination of some of these techniques, see MontSerrat, García-Alsina: Big Data. Gestión y explotación de grandes volúmenes de datos, UOC, Barcelona, 2017, pp. $93 \mathrm{ff}$.
} 
of microdata, mass data, or Big Data, occupying a predominant position in the field of economic activity.

\subsection{The concept and characteristics of Big Data}

The term 'Big Data' is often used in a vague, imprecise way, allowing for different interpretations. However, the definitions that do exist are normally based on the structural features of this new type of information, such as the existence of a large amount of data, and the impossibility of analysing them to extract any type of useful information by using traditional methods 9 .

One of the most widespread description of the characteristics of Big Data, used by the majority of authors and administrative bodies, consists of the four 'Vs': volume, variety, velocity (of processing) and veracity ${ }^{10}$.

Their volume can be seen in the fact that the data are classified as "massive" or "microdata." This refers to the accumulation of vast amounts of data and their exponential growth, as a result of the ubiquitous nature of network activity, and its ability to constantly generate digital data.

The velocity with which data is generated, accessed, processed, and analysed has also increased, with some applications making it possible for these actions to be carried out in real time ${ }^{11}$.

Also, the data may be highly varied, in terms of its type, format, or the structures used to present it. The possibility of gathering data from a wide range of sources allows companies to not only access "traditional" information on their clients, such as their address (both their physical and IP address), age or gender, but also other types of contents, such as their dietary habits, ideological tendencies, purchasing history, or the places where they have travelled or plan to travel.

The final " $v$ " refers to veracity: the data that undertakings hold on their clients must be accurate and consistent, allowing them to make the right decisions and analyse the data in detail ${ }^{12}$.

\footnotetext{
${ }^{9}$ See ad.ex., the definition suggested by JAVIER, PUYOL MonTERO, cit., p. 10, who notes that this is "an expression used in technology to refer to the information or collection of data which, due to its excessive volume, diversity, and complexity, cannot be stored or visualised using traditional tools."

${ }^{10}$ For a detailed examination of these aspects, see MAURICE E.,StUCKE/Allen P., Grunes: Big Data and Competition Policy, Oxford University Press, Oxford, 2016, pp. 15 ff.; DANIEl L., Rubinfeld/Michal, S. GAL: "Access Barriers to Big Data", 59, Arizona Law Review, 2017, pp. $345 \mathrm{ff}$. Some authors add more " $\mathrm{v"}$ to this characterization: verification; variety; viability. MONTSERRAT, GARCÍA-ALSINA, cit., pp. $28 \mathrm{ff}$. ${ }^{11}$ OCDE: Big Data: Bringing Competition Policy to the Digital Era, 2016, pp. 6-7.

${ }^{12}$ MAurice E.,Stucke/Allen P., Grunes, cit., p. 22, highlight the interconnection between Big Data and Big Analytics.
} 
The use of the new technologies and analytics of Big Data can be enormously advantageous for companies, helping them to improve their decision-making processes and their performance, leading in turn to benefits for their clients, employees, and for the economy and society in general ${ }^{13}$. The data can also be used as an input, in the same way as capital or labour, in the development of a company's activity. Companies mainly use analytical techniques for mass data in order to obtain more detailed knowledge about their clients, and to make forecasts about how they will behave. Identifying the opinions, needs, and appraisals of their clients allows companies to improve their existing products and services, and to exploit new business opportunities. This makes it easier for companies to evaluate their products by analysing this data, obtaining valuable information that allows them to create new products, or re-design existing products. Companies can predict how market trends will change and act accordingly, improving the efficiency of the production or distribution process.

In turn, by obtaining specific knowledge it is possible to segment clients and allow companies to orientate their services, satisfying their needs in a more specific way, through recommendations or more personalised publicity campaigns.

Also, in two-sided markets, by converting data policies into an essential asset in the design of competitive strategies, the need to constantly access new information or increase their existing databases leads companies to compete by improving or offering consumers different services that allow them to access their data, and which are generally provided at a low or zero cost (known as data-driven innovation) $)^{14}$.

This said, the rise and consolidation of this new data economy is not without controversy, and while it is true that using Big Data methods or techniques can lead to major benefits for consumers and the public at large, a series of risks or possible negative effects have been identified, associated with the use of massive amounts of information by companies. The negative facet of Big Data has mainly focused on the possible violation of consumers' or clients' right to privacy. In the digital age, individuals leave a trace of all of their activities, through searches, purchases, journeys or articles they have read, producing vast amounts of information each day that are compiled and monetarised by companies, either directly or by selling them on to third parties. Each digital footprint can be used to recreate the daily life and behaviour of groups or individuals. As a result,

\footnotetext{
13 The aim of this article is limited to the possible impact on the competitive development of markets as a result of the use of data policies by companies. However, the new possibilities for capturing and processing data can also be used by public authorities for matters of general interest (identification of social habits and problems, management of pandemics, understanding climate change, improvement of public services, etc.). See, in extenso, JAVIER, PUyOl Montero, cit., pp. 81 ff. MontSERrat, GarcíA-Alsina, cit., pp. 85 ff.

${ }^{14}$ See DANiEl,SOKOl / Roisin, COMERFord: "Does Antitrust Have a Role to Play in Regulating Big Data? Cambridge Handbook of Antitrust, Intellectual Property and High Tech, Cambridge University Press, 2016, available at SSRN: https://ssrn.com/abstract=2723693
} 
the larger the footprint that is identified, the more intimacy or privacy is $\operatorname{lost}^{15}$. New technologies make it possible to create consumer profiles more easily and precisely, and consumers may not be aware of their personal information being sold on, or at least the scope of this process ${ }^{16}$.

Furthermore, the dark side of Big Data is not only limited to violating people's privacy. In recent years, antitrust law has focused on the debate between its positive and negative aspects. The European Commission and competition authorities of the Member States and other jurisdictions, such as the USA, are gradually taking a less wary approach towards the risks of Big Data for the development of the competitive process in their markets. It is equally significant that documents have appeared that analyse the recent interrelations between Big Data and antitrust law, together with investigations and proceedings against leading companies in the gathering or accessing of online data, a good example of which is the recent, high-profile fine imposed by the Commission on Google for its abuse of a dominant position ${ }^{17}$. A heated debate has arisen between staunch defenders of Big Data and its pro-competitive nature, and other more distrustful opinions, which have drawn attention to the possibility that the gathering and exploitation of data may be used by companies as a means of creating, consolidating, or increasing their positions of market power ${ }^{18}$. This debate has now formed a part of the discussion of whether antitrust law is the most suitable way of dealing with the risks or hazards that

\footnotetext{
${ }^{15}$ In the United States, the case of the Target self-service store became famous, as it was able to predict a young woman's pregnancy by analyzing the behavior and preferences of its customers. See the case description and an analysis of the data strategies used by the US company in "How companies learn your secrets", article in the New York Times, 16 February 2012

${ }^{16}$ In order to deal with the risks of possible negative effects on the right to privacy and privacy of the subjects and their control of the information about them that exists online, the different rules on data protection obey the different rules on data protection and the work of specific administrative organisations, such as the European Data Protection Agency.

${ }^{17}$ Commission decision 39740 of 27 June 2017, Google Searches (Shopping).

${ }^{18}$ This essentially US doctrine has echoed this debate. Amongst others, see: MAURICE E.,STUCKE/AlLEN P., Grunes: Big Data and Competition Policy, cit.; IDEM: "Debunking the Myths Over Big Data and Antitrust", CPI Antitrust Chronicle, 2015; IDEM: "Data-opolies", 2017, available at ssrn.com/abstract= 2927018; IDEM: "No Mistake About It: The Important Role of Antitrust in the Era of Big Data", Antitrust Source, 2015, available at https://ssrn.com/abstract=2600051; DAVID BALTO/MATTHEW, LANE: "Monopolizing Water in a Tsunami: Finding Sensible Antitrust Rules for Big Data", 2016, available at SSRN: https://ssrn.com/abstract=2753249; DANIEL, SOKOL/ROISIN,COMERFORD: "Does Antitrust Have a Role to Play in Regulating Big Data?,cit.; IDEM: "Antitrust and Regulating Big Data", 23, George Mason Law Review, 2016, pp. 1129 \& ff.; ANDRES, LERNER: "The Role of Big Data in Online Platform Competition", 2014, available at: https://ssrn.com/abstract=2482780 or http://dx.doi.org/10.2139/ssrn.2482780; NATHAN, NEWMAN: "Antitrust and the Economics of the Control of User Data", Yale Journal on Regulation, Vol. 30, No. 3, 2014; BJoRn, LundQvist: "Big Data, Open Data, Privacy Regulations, Intellectual Property and Competition Law in an Internet of Things World", 2016 available at: https://ssrn.com/abstract=2891484; Darren S, Tucker/Hill Wellford: “ Big Mistakes Regarding Big Data", Antitrust Source, 2014, available at: https://ssrn.com/abstract=2549044; GeOFFrEY A.,MANNE/BEN, SPERRY: "The Law and Economics of Data and Privacy in Antitrust Analysis", 2015, available at: https://ssrn.com/abstract=2418779; IDEM: "The Problems and Perils of Bootstrapping Privacy and Data into an Antitrust Framework", CPI Antitrust Chronicle, 2015: RAMSI, WoODCOCK: "Big Data, Price Discrimination, and Antitrust", Hastings Law Journal, Vol. 68, 2017; GIUSEPPE, Colangelo/Mariateresa, Maggiolino: "Data Protection in Attention Markets: Protecting Privacy Through Competition?", 2017, available at https://ssrn.com/abstract=2945085; KeNNETH, BAMBERGER/ ORLY, LOBEL: "Platform Market Power", Berkeley Technology Law Journal, Vol. 32, No. 3, 2017.
} 
may affect consumers as a result of the dissemination of data-based business models, and that if it is, whether the traditional techniques and criteria of antitrust law are appropriate for these sectors, or if new criteria have to be applied.

\section{THE PHENOMENON OF BIG DATA FROM THE PERSPECTIVE OF ANTITRUST LAW}

\subsection{A change of course by the competition authorities}

Over the last few years, competition authorities have changed their attitude towards the risks posed by Big Data policies, having detected growing concerns as a result of increasing concentration of data-associated markets and a fear of anti-competitive behaviour by the leading companies that control vast amounts of personal information. As previously indicated, the publication of a series of documents ${ }^{19}$ that evaluate the implications of Big Data from an antitrust perspective, and a more aggressive approach towards the application of regulations by the competition authorities ${ }^{20}$ are clear indications of these new concerns, and that the control of information has ceased to be an irrelevant or insignificant aspect within the framework of antitrust law.

In order to be able to understand the current orientation of the administrative authorities with regard to the possible risks that the command of vast amounts of data may entail in terms of competition, it should be remembered that until quite recently, investigations into the digital markets of large companies in the sector were focused on tradition sources of acquiring market power, such as the control of infrastructures or the ownership of industrial or intellectual property. The possibility of a company acquiring a dominant position as a result of controlling personal information was considered unrealistic. This, together with the existence of guaranteed benefits for consumers associated with the use of Big Data techniques by companies, with "free" services, qualitative improvements in the platforms or of the products or services offered, as well as more precisely targeted advertising, was a decisive factor in the limited relevance of Big Data in antitrust analyses, and in the fact that the possible risks or problems that may

\footnotetext{
${ }^{19}$ See Bundeskartellamt/Autorité De la CONCURRence: Competition Law and Data, cit.; AUTORITAT CATAlana de la COMPETÉnCIA: La economía de los datos. Retos para la competencia: cit.; OCDE: Big Data: Bringing competition policy to the digital era, cit.; EuropeAn DATA ProteCtion AgEnCY: Privacy and competitiveness in the age of big data. The interplay between data protection, competition law and consumer protection in the Digital Economy, 2014.

${ }^{20}$ The corporate policies of the sector's giants are being scrutinised by the European Commission and the Member States' competition authorities. In this sense, in the European framework, investigations have begun with Facebook in relation to new behaviors and operations that have been favorably judged and that have now raised new misgivings, such as the concentration between Facebook and the WhatsApp platform. In December 2016, the Commission sent a statement of objections to Facebook, alleging that the company had provided misleading information about its alleged privacy policy during the investigation into the WhatsApp merger. Also in 2016, the Bundeskartellamt initiated proceedings against Facebook for possible abuse of its dominant position in the social networking market. This all took place against the backdrop of the Commission's controversial sanctioning of Google, accused of having abused its dominant position in the browser market for favouring its own price comparison services and the existence of other investigations involving the US giant for the use of the Android operating system.
} 
have arisen were entrusted to other sectors of the legal system, such as specific data protection regulations, or consumer law.

Nevertheless, the rise of corporate giants in the provision of specific online services has unleashed the fear amongst competition authorities that the increased gathering and processing of information may lead to increased concentration in the markets and give rise to antitrust behaviour, which in turn has led to the reconsideration of the two main premises that underpinned this previous neglect: that data are not an ideal source of market power and the erection of entrance barriers, and that the protection of privacy is not an objective contemplated by competition law. As a result, new concerns have arisen, which have taken shape in the redefinition of how these prohibitions are applied: new definitions of the relevant markets and theories regarding anti-competitive effects, as well as new possibilities for harming or damaging consumers.

\subsection{Big Data and market power}

Market power is a key element in competition law, and the policy for applying its regulations. All of the prohibitions that affect business behaviour finally end up revolving around the concept of market power, considered in legal terms as the possibility of independent or autonomous behaviour by companies operating in the market ${ }^{21}$. Controlling concentrations between companies is precisely aimed at preventing the creation of positions of unilateral or collective positions of power in the marketplace. A dominant position is a requisite to be able to demonstrate the existence of abuse as prohibited by Article 102 of the Treaty on the Functioning of the European Union (and its national equivalents), and the possibility of exemption of restrictive agreements indicated in Article 101 of the TFEU largely depends on whether the parties involved have market power or not. Therefore, market power and the abusive use of the same lie at the core of competition law, without which the free market forces themselves will prevent harm being caused to consumers, the final beneficiaries of its regulations.

Traditionally, the economic and legal doctrine and competition authorities have contemplated with great scepticism, with regard to online business, the possibility that merely having control over data, regardless of their volume, could be sufficient to give a company market power, and therefore constitute a concern in antitrust terms.

\footnotetext{
${ }^{21}$ Despite its importance, the concept of market position is not defined in the Treaty, and instead it is dealt with by the Commission and the CJEU in their work and application of the regulations, fundamentally in cases involving the abuse of dominant positions. rejecting definitions of an economic nature, which are included in other systems, such as in the usa, which focus on the ability of the dominant company to substantially restrict market production, in Europe a dominant position is considered as: "a position of economic strength enjoyed by an undertaking which enables it to prevent effective competition being maintained on the relevant market by giving it the power to behave to an appreciable extent independently of its competitors, customers and ultimately of its consumers" (Judgement of the Court of 14/2/1978, case 27/7United Brands).
} 
It is true that the data economy has as a unique facet the habitual presence of network effects in the markets that are involved, especially in the case of two-sided markets, which means that the value of a product or service depends on the number of users it has. For example, the larger the number of users a platform has, the more valuable it will be for advertisers. In structural terms, these network effects usually lead to the concentration of this activity in the hands of a very small number of enterprises ${ }^{22}$.

This said, having high market shares does not necessarily mean having market power. In this sense, a series of economic characteristics of data have been noted which determine that accumulating them does not necessarily entail the creation of barriers to entry, and does not automatically grant the company that owns them the incentive or ability to exclude competing companies, expand or consolidate its own position of dominance, or harm its competitors in any other way ${ }^{23}$.

Firstly, it is normally said that the majority of the digital markets -within which the markets associated with data comprise a subtype or category-are characterised by the fact that barriers to entry are absent or unimportant. They are very dynamic markets, in which the key aspect in terms of competition is not the price, but instead innovation, which makes it easier for companies that appear with novel products or services to gain favour with consumers, and quickly obtain the information they require in order to improve their offer and displace the existing companies ${ }^{24}$. This statement is normally supported by the example of companies such as Google or Facebook, who were able to oust well-established operators such as Yahoo or Lycos in the first case, and My Space in the second. ${ }^{25}$. The European Commission itself defended the ease of entry of digital applications for consumers into the markets, against the backdrop of the concentration between Facebook and WhatsApp ${ }^{26}$.

In any event, it has been defended that the economic characteristics of personal data -their pervasiveness, low cost, extensive accessibility and obsolescence- would

\footnotetext{
${ }^{22}$ On the different network effects that may be present in data markets, see in extenso MAURICE E.,Stucke/Allen P., Grunes: Big Data and Competition Policy, cit., pp. 200 ff.; Autoritat Catalana DE LA COMPETÉNCIA: cit., pp. $11 \mathrm{ff}$.

${ }^{23}$ See Daniel, Sokol/Roisin, Comerford; "Antitrust and Regulating Big Data", cit.; Darren S, TuCKer/Hill, Wellford: cit.; DAVid Balto/Matthew, Lane, cit.

${ }^{24}$ The former Executive Chairman of Google, Eric Schmidt, minimised any possibility of anti-competitive effects arising from the conduct of its business by referring to the open nature of digital markets. "The barriers to entry are negligible, because competition is just one click away", "The Tinkerer's Apprentice", available at https://www.project-syndicate.org/commentary/google-european-commission-and-disruptivetechnological-change-by-eric-schmidt-2015-01.

${ }^{25}$ See DarRen S, TUCKer/Hill WellFord, cit., p. 7.

${ }^{26}$ Commission decision M.7217 of 3 October 2014, Facebook/WhatsApp, paragraph 132: "consumer communications apps are a fast-moving sector, where customers' switching costs and barriers to entry/expansion are low. In this market any leading market position even if assisted by network effects is unlikely to be incontestable. The market of consumer communications apps has a long track record of entry by new players. Also, competing consumer communications apps are able to grow despite network effects, both over time and following disruptions in the market. Such a threat from new players constitutes and is likely to keep constituting a significant disciplining factor for the merged entity, regardless of the size of its network".
} 
prevent a company from acquiring market power by gathering and making use of them, regardless of the size of the amounts of data handled.

Data are ubiquitous and easy and affordable to obtain. Big Data is everywhere, ${ }^{27}$ and the sources of online data are constantly growing, something that is expected to become even more intense in the future, with the full consolidation of the technologies of the Internet of Things.

Also, unlike other inputs, the use of data by a company does not exclude their possible use by third parties. The exclusive appropriation of data is impossible: the fact that specific information is obtained by one company does not prevent others from accessing it by using the same or other methods. Consumers can share their data with multiple companies. In fact, multiconnection or multihoming, the use of multiple supports to obtain the same service, can be an important factor in the destabilisation of positions of market power. Ultimately, companies can also acquire data or information they require from a third party, with numerous data brokers operating in the market dedicated to the storage, analysis, and sale of information.

Data soon become obsolete and useless. The possession of large databases is not a significant advantage, unless they are constantly updated and scrupulously organised.

Finally, the value of personal information does not lie in its quantity, but instead in the ability of a company to exploit it, with the algorithms and technologies used being much more important than the data itself. The combination of different data sources as a result of a corporate or other type of merger does not necessarily signify an improvement in the ability of the companies to exploit these data.

In summary, having control over data cannot give rise to the construction of entrance barriers, and therefore to the existence of positions of market power. They are not an essential element in order to compete, and in any event there are affordable ways of accessing them, either directly or indirectly, by acquiring them from third parties.

These claims about how digital markets function, and corporate Big Data policies, despite their undoubted appeal and forcefulness, are not universally accepted. Some of these premises are being called into question, both from the point of view of doctrine and from that of the competition authorities, and their soundness or, at least, the categorisation with which they are presented is being questioned. In fact, the main criticisms focus on the lack of validity of these statements as general rules. Not all markets in the digital economy are the same, with some markets experiencing fierce competition and continued substitution between economic operators and greater stability in others, with companies

\footnotetext{
${ }^{27}$ In fact, the ubiquity of the data and the possibility of using alternative sources of information to obtain it formed the basis of the reasoning behind the FTC's and the European Commission's authorisation of two major mergers in these sectors: the Google/Double Click transaction and the acquisition by Facebook of the WhatsApp platform.
} 
with high and stable market shares. The existence of competition in one market does not exclude the possibility of barriers to entry in another, nor does it exclude that past results of entry into one market necessarily imply that this will happen in the future. Revisionist positions warn of the risks of taking things for granted and point to the need to examine them on a case-by-case basis, bearing in mind that the particular circumstances of different markets differ and that the barriers to market entry associated with data are not invariably high or low. Each industry can be different

Thus, while it is true that the existence of network effects can be seen as a destabilising element of previous market power positions if new entrants are able to attract a significant number of users by offering innovative products or services, thereby displacing incumbents, it can also be a factor leading to market concentration and the creation of barriers to entry. Indeed, two-sided markets are often highly concentrated markets with natural oligopolistic characteristics and high entry costs, as a result of the need to develop both sides of the market in order to compete. These markets also carry a structural risk, as they have the problem of the only winner (winner takes all), which usually occurs when the value of the network is very high, the costs of multi-connection are very high, and there is less differentiation in demand between users. The activity is therefore concentrated in a very small group of "leading" companies, leaving the rest in purely residual positions.

The network effects and the subsequent exclusion of other competitors may also be reinforced in these markets by what is known as the 'feedback loop' of automatic learning algorithms. The more users a platform has, the more data it has at its disposal and the algorithms used to determine the intentions and preferences of its users will yield more accurate results: more relevant search results, more targeted ads or more relevant product recommendations. The more accurate and personalized the customer identification, the more value the platform will have for advertisers and the more they will pay to reach their potential buyers.

The intended accessibility of the data has also been questioned. The availability of alternative data sources will also vary according to markets. A perfect multihoming or multi-connection situation is rare in practice, due to the existence of various switching costs (learning, network effects, etc.) which make it difficult for consumers to use several providers in the same proportion. Some business strategies related to sector data policies seem to contradict the intended dynamism of digital markets and the widespread and affordable availability of information: how do you reconcile the defended ubiquity and accessibility of data with the costly policies of providing services at no cost by platforms to maintain and develop their database? And with the very costly concentration operations carried out by the platforms for acquiring companies that can only be explained by the portfolio of data they can provide?

Access to data and information based on it is a strategic and valuable asset for companies. The control of a significant database and efficient information analysis 
technologies undoubtedly represent an important competitive advantage over rivals. Companies can therefore use a variety of strategies to maintain or reinforce this advantage and exclude third parties from access to the data, such as reaching exclusivity agreements, or company acquisition operations. The success of these types of manoeuvres and the possible negative impact on the structure and development of the competitive process in the markets cannot be ruled out a priori, i.e. the possibility cannot be automatically ruled out that this advantage could lead to the formation or consolidation of a position of market power, especially when the size of the data controlled or the value of the analysis technologies are key to competition and cannot be replicated by third parties. The existing debate highlights, in our opinion, the difficulty of identifying valid universal features about the functioning of data markets that can be used without considering the specific case in judging whether an action is anticompetitive or not.

\subsection{The application of antitrust regulations: possible risks for competition}

2.3.1. The adaptation of traditional instruments and privacy as an interest protected by competition law

Having ruled out the innate harmlessness of business policies associated with Big Data from the perspective of competition law, it is now necessary to identify the factors that are present in these markets and the behaviour of economic operators that may cause antitrust problems, evaluating them in terms of the different types of prohibited practices: concentrations, collusive arrangements, and abuse of a dominant position.

However, before proceeding with the analysis of each of these categories in a specific manner, it is advisable to make two general considerations that affect all of them. These considerations are derived from the characteristic features of this new data economy, as well as from the need to clarify the role, if any, of antitrust law in dealing with infringements of the right to privacy of individuals

Firstly, the special characteristics of these markets mean that many of the tools currently used in antitrust analysis, which are highly focused on the prices of products or services, are not appropriate in some of the digital markets, notably in multi-sided markets, especially where products or services are offered free of charge. In this sense, an essential step in antitrust analysis is the delimitation of the relevant markets, which is traditionally carried out on the basis of criteria such as demand or supply substitutability, measured using the so-called hypothetical monopolist test or SSNIP test, according to which the minimum group of products is estimated for which a hypothetical monopolist would find it possible and beneficial to make a price increase of between 5 and $10 \%$ in of the same market (small but significant non-transitory increase in prices) ${ }^{28}$. The test presupposes that the product or service in question is offered for a monetary price and is

\footnotetext{
${ }^{28}$ European Commission communication of 9 December 1997, on the definition of relevant market for the purposes of Community competition law (OJEC C372/5).
} 
therefore not suitable for identifying a market when the service is offered for 'data' or 'information'." ${ }^{29}$ As an alternative criterion to the SSNIP test, the SSNDQ test has been proposed, which would evaluate the responses from the users of a service as a result of a "small but significant non-transitory decrease in quality." 30

Competition authorities have traditionally focused on only one of the many sides of a market, the paid side, to determine the possible impact on competition, although in recent pronouncements the possibility seems to be opening up to assess the impact of business conduct on the provision of free platform services to their customers as well. ${ }^{31}$

A second, interrelated issue, which necessarily has to do with the development of the relationship between competition law and Big Data, is the determination of the role of this sector of the legal system in the protection of the privacy of subjects. While references to the possible impact of the right to privacy are not unrelated to antitrust analysis, particularly in the area of merger control, competition authorities tended to reject the adequacy of antitrust rules to address possible infringements of this right by referring to other legal branches, such as consumer law and specific data protection rules. ${ }^{32}$

However, in the last two years, both the Commission and the national competition authorities have started to consider the loss of control over personal information and the violation of the right to privacy as potential competitive harm. The documents published by various authorities and the Commission's most recent pronouncements, such as the Microsoft/LinkedIn case, therefore appear to announce a change of direction in which the

\footnotetext{
${ }^{29}$ Indeed, in Germany, the fact that the services were offered at zero cost made it impossible to identify or establish the existence of a relevant market for the purposes of the antitrust analysis, and this is the solution advocated by certain sectors of the US doctrine. See ad.ex., DARREN S, TUCKER/HILL, WeLlford, cit., pp. $6 \mathrm{ff}$.

${ }^{30}$ See OCDE: Big Data: Bringing Competition to the Digital Era, cit., pp. $16 \mathrm{ff}$.

${ }^{31}$ In this sense, in the assessment of the merger between Facebook and WhatsApp, the analysis of the possible anti-competitiveness focused on only one of the sides of the market involved, of online advertising on the platforms -in other words, on the relationship between the platform and its advertising customersbut it did not assess the market for social network services (platform-consumers). In the Google case, however, the Commission carried out a much broader market delineation, assessing the effects of the behaviour of the dominant company in the browser market on the price comparison market. Also in the context of the merger between Microsoft and LinkedIn, particular attention has been paid to the market for social network services. In a similar vein, the Bundeskartellamt, in its recent investigation against Facebook for alleged abuse of a dominant position, expressed concern that the company's practices will affect competition in the social networking market.

${ }^{32}$ See the speech by the Competition Commisioner Margrethe Vestager, on 17 January 2016, "Competition in a big data world", available at https://ec.europa.eu/commission/commissioners/20142019/vestager/announcements/competition-big, in which she expressly refers to the inconvenience of applying competition policy to solve privacy issues: ... "The real question isn't whether companies are competing to offer more privacy but for us to have adequate data protection rules in place. I don't think we need to look to competition enforcement to fix privacy problems...". Similarly, in the Facebook/WhatsApp case, which raised privacy concerns for users of both networks, the Commission considered that: '..the Commission has analysed the potential concentration of information only in relation to its strengthening of Facebook's position in the digital ad market or any subsegment thereof. Any privacy issues arising from the increased concentration of data within Facebook's control as a result of the transaction do not fall within the scope of European competition rules but within the scope of data protection at European level" (paragraph 164).
} 
consequences for privacy resulting from an increase in data concentration will be included in the antitrust analysis, seeking links of more or less solid foundations. ${ }^{33}$. Thus, it is assumed that the well-being of users not only depends on the price they pay for the service, but also on the quality of the service and the variety of the offer at their disposal. Among the qualitative variables of the competition is the privacy of their data. An increase in private data collection could be analysed either as a price increase (data is the new currency in the Internet) or as a worsening of the quality of the services provided.

Also, on the basis of the effect on competition, doctrine and authorities propose a series of remedies aimed at solving or mitigating the problems for privacy that may arise from the accumulation of data in one or a few companies. The proposals include measures such as the creation of global privacy standards, the recognition of the right to data portability, or the obligation to ensure access to data. ${ }^{34} \mathrm{We}$ consider that these are regulatory solutions that are difficult to anchor in antitrust law, both in terms of their objectives and their application, and which would be more appropriate within the specific regulatory framework of data protection.

\subsubsection{Collusive practices}

Although the debate on the potential competition risks of Big Data's policies has largely been raised from the perspective of the possible acquisition of market power as a result of information control and, therefore, in relation to the operationalisation of merger control and abuse of dominant position rules, the possibility of coordinated behaviour in data-related markets and thus the applicability of the prohibition of restrictive agreements or collusive practices cannot be ruled out.

The increasing availability of digital information about prices and other product features on the Internet, and the possibility of this information being acquired and processed in real time, greatly enhances the transparency of digital markets. Transparency in the market can have ambiguous effects. On the one hand, consumers are more and better informed about prices, quality and purchasing conditions. However, on the other hand, price transparency may limit competition by encouraging collusion between competitors by facilitating the detection of deviations from the possible agreement (whether tacit or explicit) ${ }^{35}$. This risk can be increased in digital markets, given the existence of dynamic pricing systems that are continually updated. So-called 'price-bots', pricing algorithms, can evaluate and adjust prices in seconds, considering a myriad of

\footnotetext{
${ }^{33}$ In fact, the alleged abuse that led to the Bundeskartellamt opening the investigation against Facebook was the company's violation of data protection regulations.

${ }^{34}$ See Autoritat Catalana De la Competéncia: La economía de los datos. Retos para la competencia, cit., pp. $24 \mathrm{ff}$.

${ }^{35}$ The success and sustainability of a coordinated action between competing companies requires the concurrence of several conditions. Firstly, any agreement or cooperation involves an initial difficulty, which is the determination of its terms and scope. Once this first barrier has been overcome, effective and credible mechanisms must be put in place to detect and punish potential offenders. The detection of diversionary behaviour requires a high degree of market transparency. versas condiciones. See in extenso, CARMEn, Herrero SuÁrez: "El problema del oligopolio en el Derecho de la competencia comunitario", Actas de Derecho Industrial, tomo XXIII, 2002.
} 
factors such as competitive prices. This gives them the ability to respond immediately to possible discounts from rivals, eliminating the incentive for competitors to lower prices. The use of algorithms to monitor the pricing policies of third parties could also be used by manufacturers to support resale pricing policies by enabling them to quickly detect any discounts made by distributors below the minimum established price.

Finally, a new hazard associated with data policies is that the use of monitoring strategies by the leader with automated price-bots may give rise to collusive behaviour, without there being any prior coordination agreement ${ }^{36}$. Hypothetically, a situation could arise in which independent algorithms, each being used by competing companies, autonomously decide that the best way of maximising the profits of their respective companies is by coordinating the price. In this type of scenario -at present, more akin to science fiction- this collusion would not be a result of human insight, but instead of that of one or more software programmes ${ }^{37}$.

What can antitrust law do to tackle the increasing risk of coordination as a consequence of using these mathematical techniques? The problem posed by these cases is the difficulty in prosecuting this type of behaviour. Firstly, transparency in the markets, in general, is highly beneficial for consumers if they can access the same information as the companies. Secondly, the use of price-bots is widespread in the digital economy, and their use cannot be considered as cause for suspicion or misgivings by the competition authorities. Thirdly (and we believe most importantly), it should be noted that Article 101 of the Treaty on the Functioning of the European Union is only applicable in cases where there is at least some kind of agreement or understanding between the companies. So in principle, this article would only apply to situations where there is coordinated behaviour in the market that results from or is based on an agreement, but would not apply to cases in which this coordination or parallelism, for example in fixing prices, is simply a result of the structural circumstances of the market, and only derives from the unilateral and rational (albeit interdependent) actions of the companies.

In situations where there is an agreement, using algorithms as an instrument to favour its implementation may be considered as a facilitating practice, considered as behaviour that helps companies to coordinate prices or undertake any other type of anticompetitive behaviour $^{38}$. The algorithm, by helping to detect any possible deviations from

\footnotetext{
${ }^{36}$ See the article "Price-bots can collude against consumers", published in The Economist on 6 May 2017.

37 See VERNAGER, speech given on 17 January 2016, "Algorithms and competition", available at https://ec.europa.eu/commission/commissioners/2014-2019/vestager/announcements/bundeskartellamt18th-conference-competition-berlin-16-march-2017.

${ }^{38}$ This term includes all of the business practices that can help to alleviate the risks and difficulties involved in any type of antitrust coordination process, reducing the uncertainty involved and the incentives to deviate from the cooperative scheme. Through these types of behaviour, the members of the oligopoly attempt to purposely change the type of market in order to allow it to adopt parallel types of behaviour, without having to resort to an express agreement. The main risk involved in these types of practices is therefore their antitrust tendency with regard to a market's specific circumstances or players, rather than any substantial anti-competitive practices. See CARMEn, Herrero SuÁreZ, cit., pp. ff.; DENnis, YaO / SuSAn, DE SANTI: "Game Theory and the Legal Analysis of Tacit Collusion", 38, Ant. Bull, 1993, p.120.
} 
the cooperative scheme, would have a similar function to the alignment clauses, or behaviour involving the exchange of information.

In any event, and despite the operational difficulties that the competition authorities will have to deal with in these situations, the Commission has already stated that the fact that price fixing results from an automatic system does not prevent it from reaching companies that use them, further stressing that companies should take antitrust standards into account in the programming and use of their price fixing algorithms (known as "antitrust compliance by design").

\subsubsection{Control over concentrations between companies}

To date, the only sector in which problems have actually arisen in terms of competition and Big Data has been concentration operations between companies. The Commission and the competition authorities of the Member States and other jurisdictions have had to examine the antitrust implications of external growth operations by leading companies in the new data economy ${ }^{39}$. The most significant operations at European level, at least in terms of the companies involved, have been the concentrations of Google/DoubleClick ${ }^{40}$, Facebook/WhatsApp ${ }^{41}$ and more recently, Microsoft/LinkedIn ${ }^{42}$.

The application of this policy to concentrations of companies operating in the data economy poses a series of practical difficulties, both in terms of the possibility of activating the control mechanism itself, as well as the categorisation of the operation and its evaluation from a substantive perspective.

Firstly, in the digital markets, we frequently see concentrations in which a large, well established company acquires a newcomer or startup which offers a novel product or service, paying a price well above its value in terms of its turnover. These are operations in which the real value of the company being acquired lies in the innovative nature of the products or services being offered, the information or data its controls, or its presence in the market in terms of the number of users of its services. The problem that arises in these cases is that the current notification thresholds that trigger the control procedure are based on the turnover of the companies involved in the operation, ${ }^{43}$ which means that these operations may not be subject to this scrutiny unless their future impact in competitive terms is evaluated. In some cases, the thresholds that focus exclusively on turnover may exclude acquisitions that have a major impact on the future development of competition in the markets, in which a relevant company, motivated by the possibility of

\footnotetext{
${ }^{39}$ For a detailed analysis of the different concentration operations carried out in digital markets associated with data, both in Europe and the USA, see Stucke, Maurice E./Grunes, Allen P.: Big Data and Competition Policy, cit., pp. $69 \mathrm{ff}$.

${ }^{40}$ Commission decision M.4731 of 11 March, Google/DoubleClick.

${ }^{41}$ Commission decision M.7217 of 3 October 2010, Facebook/WhatsApp.

${ }^{42}$ Commission decision M.8124 of 6 December 2016, Microsoft/Linkedln.

${ }^{43}$ See Article 1 Council Regulation no. 139/2004 of 20 January 2004 on the control of concentrations between undertakings.
} 
obtaining access to a variety of additional data sources, buys a smaller company it considers as having potential to generate new data, or access to valuable data ${ }^{44}$. One solution to this problem that has been suggested is the introduction of a complementary threshold, not based on turnover, but instead on the value of the transaction; this was recently applied in Germany, and was the subject of a public consultation launched by the Commission in October $2016^{45}$.

Another obstacle caused by concentrations -associated with the previously mentioned difficulty of delimiting relevant markets in this sector-is the fact that they are categorised as horizontal, vertical, or conglomerates, and the subsequent application of the corresponding substantive evaluation criteria. In many digital markets, a merger between an established company and an innovative newcomer has an insignificant impact on the existing market structure, due to its low quotas, or even the absence of horizontal overlapping. However, in the case of data markets, a merger of this kind may lead to an increase in the level of concentration of data if the new company has access to a significant database (which may be obtained, for example, in another market). Traditionally, the competition authorities have disregarded the eventual risks that may arise from the concentration of data, based on a classical analysis of the anti-competitive nature of concentrations, focusing on the presumed effect of the operation on price or production levels in relevant markets. In principle, the possibility that any such possible data benefit the new undertaking may obtain leading to the formation or consolidation of a position of economic power would be based on two circumstances: the lack of data (or problems resulting from their irretrievability) and the degree to which the scale or scope of the data affect the competitive result of the markets. These situations have not only been evaluated in the cases that have been examined, but also the attitude of the Commission in these operations has been receptive towards the allegations of efficiency and economic benefits in data gathering.

Nevertheless, as previously mentioned, in the most recent operations associated with two-sided markets, a wider approach can be seen that is not restricted to examining the anti-competitive potential of the concentration purely in terms of the prices of one of the markets, but instead seeming to extend its spectrum, identifying more relevant markets, and introducing other factors into the analysis, such as its effects on consumers' privacy $^{46}$.

\subsubsection{Abuse of a dominant position}

\footnotetext{
${ }^{44}$ Economic objectives of this kind explain concentration operations such as those between Facebook and WhatsApp (cit.), Google and DoubleClick (cit.) or Google and Waze, a platform through which users could see different aspects of traffic conditions in real time, which proved to be of great use for the maps service offered by Google.

${ }^{45}$ See http://ec.europa.eu/competition/consultations/2016_merger_control/index_en.html

${ }^{46}$ Supra.
} 
The application of prohibitions against the abuse of a dominant position associated with Big Data policies has also raised a series of questions, the majority of which, for the time being, are purely theoretical. This starts out with the previous question of whether the control of a significant database is liable to confer a dominant position in the marketplace, to the identification of behaviour or activities associated with the use of data that could be considered abusive.

In principle, neither the accumulation of data nor the capitalisation of economies of scale can be considered as anti-competitive. However, the competition authorities do not rule out the possibility of data being used as a way of creating or maintaining a position of power in the market through behaviour aimed at limiting access to this data by third parties ${ }^{47}$. In this regard, different scenarios have been designed involving exclusive behaviour related to controlling data: 'tying' or 'bundling', the refusal to supply data, or from a more exploitative approach, the use of data as a price discrimination instrument ${ }^{48}$.

\section{THE UNCERTAIN PATH THAT LIES AHEAD}

The development of the data economy, and the continuous, progressive rise of economic operators who have made the gathering and treatment of information their business model, have made it necessary to define the role that competition law has to play as a legal field responsible for organising the markets, and guaranteeing the correct development of the competitive process within them.

The Big Data economy poses new, complex questions from an antitrust perspective. The special characteristics of information as a product or input, and the existence of complex markets with interrelationships between different client groups, hinder the application of traditional analytical tools. The competition authorities are faced with a situation in which they must adapt to the rapid change of online markets, dealing with the analysis of increasingly complex cases, and the difficult task of defining a clear path to be followed by all of the different operators that are involved. The possibly negative impact of Big Data business policies is not clear. In fact, so far, the risks that have been identified are more theoretical or speculative than real, and the inclusion of aspects associated with privacy as a parameter to be evaluated in determining the competitive effect of a certain type of behaviour must be handled with great care, in order to avoid introducing distortions in antitrust analysis that affect its coherence, leading to situations of legal uncertainty.

47 See OCDE: Big Data: Bringing Competition Policy to the Digital Era, cit. pp. 20 ff.; Bundeskartellamt/Autorité de la Concurrence: Competition Law and Data, cit., pp. 17 ff.; Autoritat Catalana de la CompeténCia: La Economía de los Datos. Retos para la competencia, cit., pp. 19 ff.

${ }^{48}$ By gathering data on its clients, a company obtains more information about their buying habits, and is in a better position to evaluate their willingness to pay for a specific product or service. Providing it has market power, the company may use this information to define different prices for different consumer groups it has identified thanks to the information obtained. 


\section{BIBLIOGRAPHY}

Autoritat Catalana de la COMPeténcia: La Economía de los Datos. Retos para la competencia, 2016. Balto, David.A./LAne, MAtThew C.: "Monpolizing Water in a Tsunami: Finding Sensible Antitrust Rules for Big Data", 2016, available in SSRN: https://ssrn.com/abstract=2753249.

Bamberger, Kenneth A./Lobel, Orly.: "Platform Market Power", Berkeley Technology Law Journal, Vol. 32, No. 3, 2017.

BundeSKARTEllamt/Autorité De la CONCURREnCE: Competition Law and Data, 2016.

Colangelo, Giuseppe/Maggiolino, Mariateresa.: "Data Protection in Attention Markets: Protecting Privacy Through Competition?”, 2017, available in https://ssrn.com/abstract=2945085.

Ezrachi, Ariel/Stucke, Maurice.E: Virtual Competition. The Promise and Perils of the AlgorithmDriven Economy, Harvard University Press, Masssachusetts, 2016.

AlCARAZ, Fuensanta: "Mercados de doble cara (I): Características y estrategia", 2017, available in http://blognewdeal.com

GarcíA-Alsina, MontSerrat: Big Data. Gestión y explotación de grandes volúmenes de datos, UOC, Barcelona, 2017.

Herrero SuÁrez, CARMen.: "El problema del oligopolio en el Derecho de la competencia comunitario", Actas de Derecho Industrial, tomo XXIII, 2002.

LERnER, ANDRES V: "The Role of Big Data in Online Platform Competition", 2014, available in: https://ssrn.com/abstract=2482780 or http://dx.doi.org/10.2139/ssrn.2482780.

LundQvist, BJORN: "Big Data, Open Data, Privacy Regulations, Intellectual Property and Competition Law in an Internet of Things World", 2016 available in: https://ssrn.com/abstract=2891484

MAnne, Geoffrey A./SPERry, Ben: "The Law and Economics of Data and Privacy in Antitrust Analysis", 2015, available in: https://ssrn.com/abstract=2418779.

- "The Problems and Perils of Bootstrapping Privacy and Data into an Antitrust Framework", CPI Antitrust Chronicle, 2015

Newman, Nathan: "Antitrust and the Economics of the Control of User Data", Yale Journal on Regulation, Vol. 30, No. 3, 2014.

OCDE: Big Data: Bringing Competition Policy to the Digital Era, 2016.

Puyol Montero, JAVIER: Aproximación jurídica y económica al Big Data, Tirant lo Blanch, Valencia, 2015.

SOKOl, DANiel/COMERFord, Roisin: "Does Antitrust Have a Role to Play in Regulating Big Data?, Cambridge Handbook of Antitrust, Intellectual Property and High Tech, Cambridge University Press, 2016, available in SSRN: https://ssrn.com/abstract=2723693.

-“Antitrust and Regulating Big Data”, 23, George Mason Law Review, 2016, pp. 1129 ff.

Stucke, Maurice E./Grunes, Allen P.: Big Data and Competition Policy, Oxford University Press, Oxford, 2016.

-"Debunking the Myths Over Big Data and Antitrust", CPI Antitrust Chronicle, 2015.

- "Data-opolies", 2017, available in ssrn.com/abstract=2927018.

- "No Mistake About It: The Important Role of Antitrust in the Era of Big Data", Antitrust Source, 2015, available in https://ssrn.com/abstract $=2600051$.

Rubinfeld, Daniel L./Gal, Michal S.: “Access Barriers to Big Data”, 59, Arizona Law Review, 2017, pp. $345 \mathrm{ff}$.

TuCKer, DArren S.; Wellford, Hill: "Big Mistakes Regarding Big Data”, Antitrust Source, 2014, available in: https://ssrn.com/abstract $=2549044$.

WoodCock, RAMSI: "Big Data, Price Discrimination, and Antitrust”, Hastings Law Journal, Vol. 68, 2017. Yao, Dennis/De SAnti, Susan: "Game Theory and the Legal Analysis of Tacit Collusion", 38, Ant. Bull, 1993, pp. 120 ff. 